\title{
METODE TPR (TOTAL PHYSICAL RESPONSE) SEBAGAI ALTERNATIF UNTUK MENINGKATKAN KEMAMPUAN TAHAP AWAL BERBAHASA INGGRIS PADA ANAK-ANAK
}

\author{
Fauzia \\ Universitas Ahmad Dahlan \\ Email: fauzia@pbi.uad.ac.id
}

\begin{abstract}
Abstrak
Tujuan pengajaran Bahasa Inggris pada tahap awal adalah memperkenalkan Bahasa Inggris kepada anak dengan cara yang menyenangkan, sehingga metode yang digunakan juga harus disesuaikan. Salah satu metode tersebut adalah TPR. Penelitian ini menggunakan metode survey lapangan. Tujuan penelitian adalah mendeskripsikan model pembelajaran TPR sebagai alternatif untuk meningkatkan kemampuan tahap awal berbahasa Inggris pada anak. Hasil penelitian menunjukkan TPR merupakan metode yang efektif dalam pembelajaran Bahasa Inggris dalam rangka meningkatkan kemampuan tahap awal berbahasa pada anak.
\end{abstract}

Kata kunci: TPR, Inggris, Anak

\section{TPR (TOTAL PHYSICAL RESPONSE) METHOD AS AN ALTERNATIVE TO INCREASE ENGLISH CAPACITY EARLY AGE TOWARDS CHILDREN}

\begin{abstract}
The purpose of teaching English for basic level is to introduce English in a fun way, so that the methods used should also be adjusted. One such method is TPR. This study uses field surveys. The research objective was to describe the TPR learning model as an alternative to improve English competencies at early stage. The results showed TPR is an effective method of learning English in order to improve the early stages of language ability.
\end{abstract}

Keywords: TPR, English, Children

\section{PENDAHULUAN}

Mempelajari bahasa kedua adalah pekerjaan panjang dan kompleks. Seseorang bisa sukses belajar bahasa kedua apabila orang tersebut mengetahui dan memahami kompleksitas variabel-variabel yang berpengaruh di dalamnya. Selain itu, peran penting seorang pengajar yang kompeten dan mumpuni dalam bidangnyapun juga patut diperhatikan. Brown (2007: 2) merangkum beberapa hal yang patut diperhatikan ketika seseorang belajar bahasa kedua yaitu: (1) karakteristik pembelajar, (2) faktor linguistik, (3) proses pembelajaran, (4) usia dan pemerolehan,
(5) variabel instruksional, (6) konteks, dan (7) tujuan. Pada makalah hasil penelitian ini akan dibahas tentang salah satu metode yang digunakan dalam pengajaran Bahasa Inggris sebagai salah satu alternatif menarik yang bisa digunakan sebagai metode pengajaran di dalam pemerolehan bahasa kedua bagi anak-anak yaitu TPR (Total Physical Response).

Penulis tertarik untuk mengambil topik ini karena, saat ini pemerolehan bahasa kedua bagi anak-anak khususnya bahasa asing, dalam hal ini bahasa Inggris sudah menjadi fenomena besar dalam masyarakat. Anak-anak sudah mulai 
diajarkan belajar bahasa asing, bahkan ketika usia mereka masih sangat kecil. Pada usia-usia yang mereka sendiripun masih belajar untuk memahami bahasa ibu mereka sendiri dengan benar. Hal itu akan membawa konsekuensi pada tuntutan kreativitas pengajar dalam menggunakan metode pengajaran. TPR (Total Physical Response) merupakan salah satu teknik dalam pengajaran bahasa kedua pada anak-anak yang dianggap efektif pada tingkat awal kecakapan bahasa (Brown, 2007: 84)

Seperti yang telah dikemukakan di atas bahwa pengajaran bahasa kedua sangatlah ditentukan oleh variabel usia. Usia dan pemerolehan seseorang akan mempengaruhi jenis metode yang cocok seperti apakah yang dapat diaplikasikan oleh seorang pengajar. Selain usia, faktor karakteristik pembelajar bahasa juga merupakan hal yang pokok yang wajib untuk diketahui sebelumnya. (Syarkawi, 2008: 2) bahwa kemampuan pengelolaan pembelajaran yang mendidik dan semestinya harus berorientasi pada karakteristik siswa. (Harmer, 2001: 37) menyatakan bahwa usia siswa merupakan faktor yang perlu diperhatikan oleh guru, sehingga guru dapat memilih apa dan bagaimana untuk mengajar siswa berdasarkan usianya.

...The age of our students is a major factor in our decisions about how and what to teach. People of different ages have different needs, competencies, and cognitive skills; we might expectchildren of primary age to acquire much of a foreign language through play, for example whereas for adults we can reasonably expect a greater use of abstract thought (Harmer, 2001: 39).

Anak-anak dan orang dewasa mempunyai karakter yang khas dalam belajar bahasa. Masing-masing perbedaan antara anak-anak dan orang dewasa tersebut dapat dilihat dari beberapa sisi. Beberapa disebutkan oleh Brown (2001: 87-90) yaitu pada: (1) intellectual development, (2) attention span, (3) sensor input, (4) affective factors, dan autehntic, meaningful language.
(Harmer, 2001: 39) mengatakan bahwa pembelajar bahasa pada rentang usia sembilan hingga sepuluh tahun belajar dengan cara yang berbeda dibandingkan dengan yang dilakukan oleh orang dewasa pada umumnya, seperti misalnya:

1. Mereka (anak-anak) menanggapi makna bahkan jika mereka tidak mengerti kata-kata dari masing masing individu.

2. Mereka sering belajar langsung, mengambil informasi dari semua sisi, belajar dari segala sesuatu di sekitar mereka daripada hanya berfokus pada topik yang tepat mereka sedang diajarkan.

3. Pemahaman anak datang bukan hanya dari penjelasan,tetapi juga dari apa yang mereka lihat, dengar dan penting bagi mereka untuk dapat memiliki kesempatan menyentuh dan berinteraksi.

4. Anak-anak umumnya menampilkan antusiasme untuk belajar dan rasa ingin tahu tentang dunia di sekitar mereka.

5. Anak-anak memiliki kebutuhan diperhatikan dan diberi persetujuan dari guru secara pribadi.

6. Anak-anak tertarik untuk berbicara tentang diri mereka sendiri, dan merespon dengan baik. Mereka belajar dengan menggunakan diri mereka sendiri dan kehidupan mereka sendiri sebagai topik utama dalamkelas.

7. Anak-anak memiliki rentang perhatian yang terbatas; kecuali kegiatan yang sangat menarik mereka dapat dengan mudah bosan, mereka dapat dengan mudah kehilangan minat setelah sepuluh menit atau lebih.

Harmer (2001: 40) menyimpulkan bahwa dengan mengetahui karakteristik siswa, guru yang baik dapat lebih banyak memperbanyak dan memperkaya siswanya dengan berbagai pengalaman belajar yang sesuai dengan usia dan karakternya.

...In the light of these characteristics, it can be concluded that good teachers at 
this level need to provide a rich diet of learning experiences which encourages their students to get information from a variety of sources... It is not talking about classrooms where children spend all their time sitting still in rows or talking only to the teacher.Because children love discovering thing, and because they respond well to being askedto use their imagination they may well be involvedin physical movement or in a songs.

Lebih lanjut (Brown, 2001: 95) menyatakan bahwa agar berhasil mengajarkan bahasa kedua kepada anak, dibutuhkan keteram-pilan spesifik dan intuisi yang berbeda darimengajar orang dewasa. Beberapa pendekatan praktis untuk mengajar anak-anak:

a. Pengembangan Intelektual

Anak-anak (sampai usia sekitar sebelas) masih berada dalam tahap perkembangan intelektual Piaget di Brown (2001: 95) atau yang biasa disebut sebagai "operasi konkrit". Aturan, penjelasan, dan bicara bahkan sedikit bahasan yang bersifat abstrak lainnya tentang bahasa harus menggunakan pendekatan sangat hati-hati. Anak-anak berpusat pada di sini dan sekarang/ 'here and now', pada tujuan fungsional bahasa. Mereka tidak bisa dengan mudah memahami metabahasa yang digunakan oleh guru untuk menggambarkan dan menjelaskan konsep-konsep linguistik seperti: 1) tidak menjelaskan tata bahasa menggunakan istilah seperti 'present progresif' atau 'klausa relatif', 2) aturan dinyatakan secara abstrak harus dihindari, 3) beberapa konsep tata bahasa, terutama pada tingkat atas ada baiknya menunjukkan pola dan contoh tertentu, dan 4) konsep atau pola yang lebih sulit memerlukan lebih banyak pengulangan daripada yang dilakukan oleh orang dewasa.

b. Rentang perhatian/attention span: 1) Anak-anak difokuskan pada kegiatan langsung atau biasa disebut sebagai 'here and now' / di sini dan sekarang. Kegiatan harus dirancang untuk menangkap minat langsung mereka, 2) pelajaran membutuhkan berbagai aktivitas untuk menjaga minat dan perhatian, 3) guru perlu animasi dan bersikap antusias terhadap materi pelajaran., 4) rasa humor, 5) memiliki banyak rasa ingin tahu alami.

c. Masukan sensorik: Seluruh panca indera anak perlu dilibatkan. Beberapa aktivitas prinsip yang dilakukan seperti: 1) pada pelajaran dengan melibatkan aktivitas fisik, seperti role-play, bermain game, atau melakukan dengan metode TPR (Total Physical Response), 2) membuat kelompok-kelompok kecil misalnya adalah cara yang sangat baik untuk siswa belajar kata-kata, struktur dan berlatih bahasa, 3) sensory aids membantu anak-anak untuk menginternalisasi konsep, misalnya bau bunga, menyentuh tanaman dan buahbuahan, dan merasakan rasa makanan, 4) bahasa nonverbal guru sendiri juga merupakan hal yang penting karena anak-anak sangat sensitif terhadap wajah, gerak tubuh, dan sentuhan.

d. Faktor afektif: Anak-anak seringkali mempunyai rasa inovatif dalam bentuk bahasa, tetapi masih memiliki banyak hambatan yang besar. Mereka sangat sensitif. Anak-anak dalam banyak hal jauh lebih rapuh daripada orang dewasa. Ego mereka masih sedang dibentuk. Dalam hal ini guru perlu membantu mereka untuk mengatasi hambatan potensial tersebut untuk belajar.

e. Otentik, kebermaknaan bahasa: Anakanak berfokus pada bahasa baru yang bisa mereka gunakan di sini dan sekarang. (Brown, 2001: 97) menyatakan bahwa dibutuhkan individu yang sangat istimewa untuk dapat mengajar anak-anak secara efektif. Seiring dengan semua panduan ini, seorang guru 
tingkat dasar harus mengembangkan intuisi tertentu disertai dengan peningkatan pengalaman dari tahun ke tahun.

Perbedaan-perbedaan tersebutlah yang menjadi dasar untuk mengaplikasikan metode yang berbeda dalam pembelajaran bahasa kedua untuk anak-anak. Wujud karakter yang muncul sebagai akibat dari adanya tahap perkembangan pada anak dijelaskan sebagai berikut:

\section{Tahap perkembangan kejiwaan anak}

Setiap tahapan perkembangan kejiwaan anak memiliki karakteristik yang berbeda. Tiap tahapan mempunyai karakteristik yang berbeda, walau tidak dalam pengertian bertentangan, sejalan dengan perkembangan tingkat kematangan anak (Cakrawala Pendidikan, 2005: 101). Hal itu akan membawa konsekuensi logis pada adanya karakteristik yang juga berbeda dengan metode pengajaran bahasa dalam rangka pemerolehan bahasa pada anak. Kesemua tahapan tersebut merupakan informasi yang berharga dan penting untuk diketahui dalam rangka memaksimalkan proses pemahaman anak terhadap pemerolehan bahasa kedua, dalam hal ini adalah bahasa Inggris. Kondisi demikian berkaitan de-ngan perkembangan intelektual.

Berbicara masalah pertumbuhan dan perkembangan intelektual (kognitif) anak, pada umumnya orang merujuk pada teori Jean Piaget yang mengemukakan bahwa perkembangan intelektual merupakan hasil interaksi dengan lingkungan dan kematangan anak (Woolfolk, 1995: 41). Semua anak melewati tahapan intelektual dalam proses yang sama walau tidak harus dalam umur yang sama. Tiap tahapan yang datang lebih awal kemudian tergabung dalam tahapan berikutnya sebagai struktur berpikir baru dalam tahap perkembangan. Jadi, tiap tahapan kognitif kemudian merupakan akumulasi gabung-an dari tahapan-tahapan sebelumnya.
Piaget membedakan perkembangan intelektual anak ke dalam empat tahapan. Tiap tahapan mempunyai karakteristik yang membedakannya dengan tahapan yang lain. Tahapan perkembangan intelektual yang dimaksud adalah sebagai berikut (Woolfolk, 1995; Brown, 2001; Smith, tt):

Pertama: tahap sensori motor (the sensory-motor period, 0-2 tahun). Tahap ini merupakan tahapan pertama dalam perkembangan kognitif anak. Tahap ini disebut sebagai tahap sensori-motor karena perkembangan terjadi berdasarkan informasi dari indera (senses) dan bodi (motor). Karakteristik utama dalam tahap ini adalah bahwa anak belajar lewat koordinasi persepsi indera dan aktivitas motor serta mengembangkan pemahaman sebab akibat atau hubungan-hubungan berdasarkan sesuatu yang dapat diraih atau dapat berkontak langsung. Anak mulai dapat memahami hubungannya dengan orang lain, mengembangkan objek secara permanen. Dalam usia 1,6-2 tahun anak akan menyukai aktivitas atau permainan bunyi yang mengandung perulanganperulangan yang kritis. Anak menyukai bunyi-bunyian yang bersajak dan berirama. Permainan bunyi yang dimaksud dapat berupa nyanyian, kata-kata yang dinyayikan, atau kata-kata biasa dalam perkataan yang tidak dilagukan. Bunyibunyian ritmis akan memicu tumbuhnya rasa keindahan pada diri anak.

Kedua: tahap preoperational (the preoperational period, 2-7 tahun). Dalam tahap ini anak mulai dapat 'mengoperasikan' sesuatu yang sudah mencerminkan aktivitas mental dan tidak lagi semata-mata bersifat fisik. Karakteristik dalam tahapan ini antara lain adalah bahwa (i) anak mulai belajar mengaktualisasikan dirinya lewat bahasa, bermain, dan menggambar (coratcoret). (ii) Jalan pikiran anak masih bersifat egosentris, menempatkan dirinya sebagai pusat dunia, yang didasarkan persepsi dan pengalaman langsung karena masih kesulitan menempatkan dirinya di antara orang 
lain. (iii) Anak mempergunakan simbol dengan cara elementer pada awalnya lewat gerakan-gerakan tertentu dan kemudian lewat bahasa dalam pembicaraan. Perkembangan kognitif pada saat ini yang secara luarbiasa adalah perkembangan bahasa dan konsep formasi.(iv) Pada masa ini anak mengalami proses asimilasi di mana anak mengasimilasikan sesuatu yang didengar, dilihat, dan dirasakan dengan cara menerima ide-ide tersebut ke dalam suatu skema di dalam kognisinya.

Ketiga: tahap operasional konkret (the concrete operational, 7-11 tahun). Pada tahap ini anak mulai dapat memahami logika secara stabil. Karakteristik anak pada tahap ini antara lain adalah (i) anak dapat membuat klasifikasi sederhana, mengklasifikasikan objek berdasarkan sifat-sifat umum, misalnya klasifikasi warna, klasifikasi karakter tertentu. (ii) Anak dapat membuat urutan sesuatu secara semestinya, menurutkan abjad, angka, besar kecil, dan lain-lain. (iii) Anak mulai dapat mengembangkan imajinasinya ke masa lalu dan masa depan; adanya perkembangan pola pikir yang egosentris menjadi lebih mudah untuk mengidentifikasikan sesuatu dengan sudut pandang yang berbeda. (iv) Anak mulai dapat berfikir argumentatif dan memecahkan masalah-masalah sederhana, ada kecenderungan memperoleh ide-ide sebagaimana yang dilakukan orang dewasa, namun belum dapat berpikir tentang sesuatu yang abstrak karena jalan berpikirnya masih terbatas pada sesuatu yang konkret.

Keempat: tahap operasi formal (the formal operational, 11 atau 12 tahun ke atas). Pada tahap ini, tahap awal adolesen, anak sudah mampu berpikir abstrak. Karakteristik penting dalam tahap ini antara lain adalah (i) anak sudah mampu berpikir 'secara alamiah', berpikir teoretis, berargumentasi dan menguji hipotesis yang mengutamakan kemampuan berpikir. (ii) Anak sudah mampu memecahkan masalah secara logis dengan melibatkan berbagai masalah yang terkait.

\section{Perkembangan bahasa}

Anak usia 3-5 tahun: (i) pemfungsian tahap praoperasional; (ii) pengalaman pada tahap prakarsa versus kesalahan; (iii) penafsiran baik buruk, boleh dan tidak boleh, berdasarkan konsekuensi fisik dan hadiah atau hukuman; (iv) perkembangan bahasa berlangsung amat cepat, dan pada usia lima tahun sudah mampu berbicara pada level kalimat yang kompleks; (v) perkembangan kemampuan perseptual seperti membedakan warna dan mengenali atribut yang berbeda pada objek yang mirip; (vi) cara berpikir dan bertingkah laku egosentris; (vii) belajar lewat pengalaman tangan-pertama; (viii) mulai menyatakan sesuatu secara bebas; (ix) belajar lewat permainan imajinatif; $(x)$ membutuhkan pujian dan persetujuan dari dewasa; (xi) kurang memperhatikan masalah waktu; dan (xiii) mengembangkan rasa tertarik dalam aktivitas kelompok.

Anak usia 6 dan 7 tahun; (i) beralih ke cara berpikir tahap operasional konkret, anak mulai berpikir beda, menentang, dan bersikap hati-hati; (ii) pengalaman pada tahap kepandaian versus perasaan rendah diri; (iii) penerimaan konsep benar (baik) berdasarkan hadiah dan persetujuan; (iv) melanjutkan perkembangan pemerolehan bahasa; (v) mulai memisahkan fantasi dari realitas; (vi) belajar berangkat dari persepsi dan pengalaman langsung; (vii) mulai berfikir abstrak tetapi belajar lebih banyakberdasarkan pengalaman konkret; (viii) lebih membutuhkan pujian dan persetujuan dari orang dewasa; (ix) menunjukkan sensitivitas rasa dan sikap terhadap anak lain dan orang dewasa; $(x)$ berpartisipasi dalam kelompok sebagai anggota; (xi) mulai tumbuh rasa keadilan dan ingin bebas dari orang dewasa; (xii) menunjukkan perilaku egosentris dan sering menuntut.

Anak usia 8 dan 9 tahun: (i) pemfungsian tahap berpikir operasional konkret, berpikir lebih fleksibel dan hati-hati; (ii) pengalaman pada tahap kepandaian 
versus perasaan rendah diri; (iii) penerimaan konsep benar berdasarkan aturan; (iv) adanya perhatian dan penghormatan dari kelompok menjadi lebih penting; (v) mulai melihat dengan sudut pandang orang lain dan semakin berkurangnya sifat egosentris; (vi) mengembangkan konsep dan hubungan spasial; (vii) menghargai petualangan imajinatif; (viii) menunjukkan minat dan keterampilan yang berbeda dengan kelompoknya; (ix) mempunyai ketertarikan pada hobi dan koleksi yang bervariasi; (x) menunjukkan peningkatan kemampuan mengutarakan ide ke dalam kata-kata; (xi) membentuk persahatan yang khusus.

Anak usia 10-12 tahun: (i) pemfungsian tahap operasional konkret, dapat melihat hubungan yang bersifat abstrak; (ii) pengalaman pada tahap kepandaian versus perasaan rendah diri; (iii) penerimaan masalah berdasarkan kefairan ; (iv) memiliki ketertarikan yang kuat dalam aktivitas sosial, (v) meningkatnya minat pada kelompok; (vi) mulai mengadopsi model orang kepada orang lain daripada ke orang tua; (vii) menunjukkan minatnya pada aktivitas khusus; (viii) mencari persetujuan dan ingin mengesankan; (ix) menunjukkan kemampuan melihat sudut pandang orang lain; $(x)$ pencarian nilainilai; (xi) menunjukkan adanya perbedaan di antara individu; (xii) mempunyai citarasa keadilan dan peduli kepada orang lain; (xiii) pemahaman dan penerimaan terhadap adanya aturan berdasarkan perbedaan jenis kelamin.

Anak usia 13 dan adolesen: (i) pemfungsian tahap operasional formal, kemampuan untuk memprediksi, menginferensi, berhipotesis tanpa referensi; (ii) pengalaman tahap identitas versus kebingungan; (iii) mungkin beralih ke tahap otonomi moral; (iv) menunjukkan kebebasannya dari keluarga sebagai langkah menuju awal kedewasaan; (v) mengidentifikasikan diri dengan orang dewasa yang dikagumi; (vi) menunjukkan ketertarikannya pada isu-isu filosofis, etis, dan religius; (vii) pencarian sesuatu yang idealistis.

\section{Hipotesis Periode Kritis}

Periode kritis bagi pemerolehan bahasa menurut (Brown, 2001: 80) adalah periode kehidupan yang dipengaruhi faktor biologis ketika bahasa bisa dikuasai secara lebih mudah dan selepas periode ini bahasa menjadi kian sulit dikuasai. Hipotesis Periode Krisis atau CPH (The Critical Period Hypothesis) menyatakan adanya semacam jadwal biologis pada pemerolehan bahasa.

Beberapa penelitian menyatakan argumen bahwa titik kritis untuk pemerolehan bahasa kedua terjadi sekitar usia akil balik; lepas dari waktu ini orang sepertinya relatif tak mampu menguasai bahasa kedua. Argumen ini menyebabkan kepercayaan beberapa pihak bahwa setelah usia 12 atau 13 tahun orang sudah 'kehabisan bensin' untuk mencapai keberhasilan dalam pembelajaran bahasa kedua (Brown, 2001: 81). Beberapa studi empiris dalam (Brown, 2001: 82) telah menceritakan tentang partisipasi otak kiri dan kanan dalam pemerolehan bahasa, baik secara empiris dan observasional. Brown juga menyatakan implikasi dari hal tersebut adalah beberapa pendekatan dalam pengajaran bahasa, misalnya TPR tidak begitu analitis, namun lebih banyak mengedepankan kemampuan psikomotor yang lebih menyatu dengan atmosfer di kelas sangat dianjurkan. Berdasarkan hal tersebut metode TPR lebih tepat dan efektif diterapkan pada anak-anak (2001: 83).

\section{TPR (Total Physical Response)}

TPR dikemukakan pertama kali oleh James Asher (1977: 25). Ia mencatat bahwa anak-anak, saat belajar bahasa pertama mereka, terlihat banyak mendengar sebelum mereka bicara, dan bahwa kegiatan mendengar itu disertai oleh responsrespons fisik (meraih, meraba, bergerak, melihat, dan seterusnya). Ia juga memberi- 
kan perhatian kepada pembelajaran otak kanan. Menurut Asher, aktivitas motor adalah fungsi otak kanan yang pastilah mendahului pemrosesan bahasa oleh otak kiri. Asher juga yakin bahwa kelas-kelas bahasa sering merupakan tempat yang luar biasa mencemaskan dan ia berharap dapat menemukan sebisa mungkin beban stres dari pembelajar bahasa, dimana para pembelajar tak akan merasa canggung dan defensif. Maka, kelas TPR adalah sebuah kelas di mana para murid banyak mendengar dan bertindak. Sang guru mengarahkan sebuah performa: "Instruktur adalah sutradara sebuah lakon sandiwara di mana para murid adalah aktornya" (Asher, 1977; 43)

Steinberg (2000) menyatakan bahwa

Total Physical Response, frequently referred to as TPR, is very much a 'natural'type method: speech understanding precedes speech production, which, in turn, precedes reading and writing. Students are encouraged to induce rules on their own ans speak when they are ready... In any case, there is no doubt that TPR is very useful method and one which deserve attention.

Sebuah kelas khas TPR memanfaatkan mood pengarahan, bahkan pada tingkat kecakapan yang lebih tinggi. Perintah adalah cara mudah untuk pembuat para pembelajar bergerak dan santai: 'Open the window', 'Close the door', 'Stand up', 'Sit down', 'Pick up the book', 'Give it to John', dsb. Seringkali bahkan tidak diperlukan respon verbal. Sintaksis yang lebih kompleks dimasukkan ke dalam kalimat perintah: 'Draw a rectangle on the chalkboard', 'Walk quickly to the door and hit $i^{\prime} t$. Humor juga dapat dihadirkan seperti; 'Walk slowly to the window and Jump', 'Put your toothbrush in your book' (Asher 1977: 55). Kalimat berbentuk interrogatif juga dapat digunakan seperti: 'Where is the book?'Who is John?' (Murid menunjuk pada buku atau John). Akhirnya para murid, seorang demi seorang, barangkali merasa cukup nyaman untuk menjajal respons verbal atas pertanyaan-pertanyaan, kemudian mengajukan pertanyaan sendiri, dan prosesnya berlanjut.

Beberapa penelitian sebelumnya dengan metode TPR yang menyatakan keberhasilan metode ini adalah apa yang tejadi pada kelas bahasa anak-anak Jepang yang mempelajari bahasa kedua mereka yaitu bahasa Jerman, juga mengalami perbedaan. Steinberg (2000: 11):

... While hesitant in their action at first, the students soon gained in confidence, performing their tasks swiftly and with assurance. Such behavior is a direct measure of their progress in speech comprehension. Interestingly, when a videotape of this TPR German lesson was shown to Japanese students in other classes, they learned about the same number of items. They did not perform any actions but simply observed what was happening on the tape. Observation was sufficient for learning. Whether the students who performed the actions retained more over time than the students who simply observed the actions was not measured, unfortunately. TPR would predict that doing the action would solidify memory.

Dari hasil penelitian tersebut, dapat dikatakan bahwa kelas bahasa dengan metode TPR, pada awalnya anak-anak merasakan keraguan untuk melakukan instruksi seperti yang terdapat aktivitas yang menggunakan metode TPR. Namun demikian, selanjutnya mereka merasa lebih nyamandan melakukannya dengan cepat dan tenang.Bentuk ini dianggap telah dapat menunjukkan suatu peningkatan atau progress dalam kemampuan anak memahami sesuatu (speech comprehesion). Yang lebih hebat, ketika pembelajaran dengan metode TPR ditunjukkan kepada siswa Jepang di lain kelas, dan mereka tidak melakukan tindakan/latihan seperti yang ada pada kelas sebelumnya, namun mereka dengan mudah dapat mengobservasi dan memahami metode apa yang 
terjadi di dalam video tersebut dengan mudah.

\section{Bentuk Kalimat Perintah (Imperative Sentence)}

Bentuk kalimat yang biasa digunakan dalam pembelajaran dengan metode TPR adalah bentuk kalimat perintah atau imperative sentences. Kalimat perintah atau dalam bahasa Inggris disebut sebagai imperative sentences mempunyai dua karakteristik, yaitu:

(http://didi-suradin.blogspot.co.id/2013/08/kalimatperintah-imperative-sentence.html)

a. Kalimat perintah (imperative sentence) digunakan untuk memberikan perintah (command), yaitu menyuruh orang untuk melakukan sesuatu dan memberikan larangan (prohibition), yaitu melarang orang untuk melakukan sesuatu.

b. Kalimat ini menggunakan kata kerja bentuk pertama, baik katakerja yang tidak beraturan (irregular verbs) maupun katakerja yang beraturan (regular verbs).Untuk memberikan perintah atau larangan, penutur tidak perlu menyebutkan subjek-nya (pelakunya). Menggunakan kata " please /pli:z/ " untuk memperhalus perintah dan larangan. 'Please' bisa ditempatkan diawal kalimat ataupun diakhir kalimat.

Struktur kalimat dalam Bahasa Indonesia maupun dalam bahasa Inggris yang selalu membutuhkan subjek $(\mathrm{S}+\mathrm{V})$ menjadi tidak terlihat secara nyata dalam kalimat perintah. Bentuk subjek dalam kalimat perintah seringkali tidak dimunculkan secara eksplisit. Hal ini merupakan hasil asumsi bahwa ketika seseorang memberikan perintah dengan menggunakan imperative sentences, dia sedang berbicara atau melakukan komunikasi dengan lawan bicara dimana lawan bicara dalam hal ini adalah 'you' atau 'kamu'. Lawan bicara diasumsikan sudah faham bahwa subjek yang diaksud dalam kalimat perintah adalah 'you' atau 'kamu' baik dalam bahasa lisan maupun tulisan.

Tabel 1. Struktir Kalimat Perintah

\begin{tabular}{ll}
\hline \multicolumn{1}{c}{ Imperative } & Subject \\
\hline Please find my yellow leotard. & (you) \\
Shut the door! & (you) \\
Be there at 5:00. & (you) \\
\hline
\end{tabular}

Diagram 2. Penggunaan kata 'you' dalam kalimat perintah bahasa Inggris
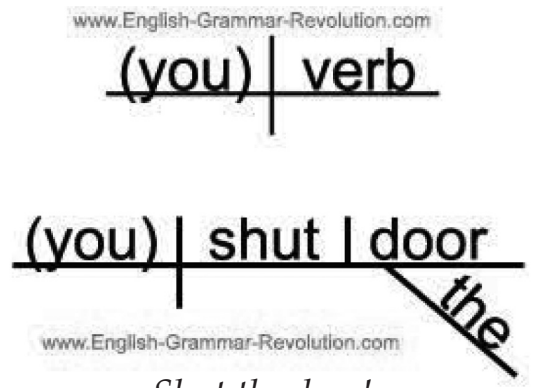

Shut the door!

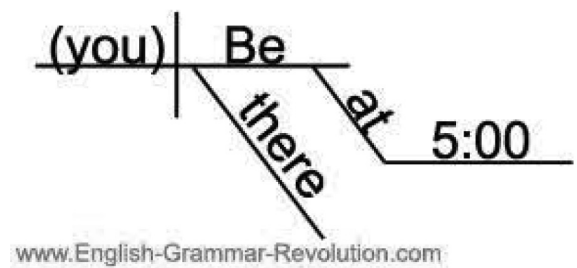

Be there at 5:00.

(http://www.english-grammar-revolution.com/ imperative-sentence.html)

Berikut beberapa contoh penggunaan bentuk kalimat perintah dan larangan yang biasa digunakan dalam aplikasi pembelajaran dengan metode TPR: 
Tabel 2. Contoh kalimat perintah dan larangan yang digunakan pada pembelajaran dengan metode TPR pada anak

\begin{tabular}{ll}
\hline Kalimat Perintah & Kalimat Larangan \\
\hline Take the Chalk & Don't go away \\
Sweep the Floor & Don't enter \\
Open the Door & Don't touch \\
Take the Broom & Don't take it \\
Come here & Don't cross \\
Stop & Don't turn around \\
Repeat & Don't leave it \\
Listen & Don't park here \\
Sit down & Don't stop here \\
Get out & Don't pass here \\
Hurry up & Don't cheat \\
Move & \\
Switch off & \\
Go back & \\
\hline
\end{tabular}

\section{METODE}

Metodologi yang digunakan dalam penelitian ini adalah metode survey lapangan, dimana peneliti terjun ke lapangan untuk melihat kondisi lapangan. Saat terjun ke lapangan, peneliti menggunakan panduan observasi yang berisi beberapa parameter yang akan diamati. Beberapa parameter tersebut merupakan faktor penentu keberhasilan dari sebuah pembelajaran, diantaranya adalah: a) guru, b) siswa, c) setting kelas, d) materi, dan e) proses evaluasi yang dilakukan.

Faktor guru/tenaga pengajar merupakan faktor utama dalam sebuah sistem pembelajaran. Tenaga pengajar memegang peranan penting kaitannya dengan proses pembelajaran. Harold B. Allen (Brown, 2001: 51) menyatakan bahwa seorang guru bahasa yang baik seharusnya memiliki beberapa kriteria sebagai berikut: 1) mempunyai kompetensi yang baik dalam persiapan pembelajaran, 2) mencintai bahasa Inggris, 3) mempunyai pemikiran yang kritis, 4) memiliki kemampuan untuk meningkatkan kompetensi diri, 5) self-subordinasi, 6) kesiapan untuk bekerja ekstra,
7) kemampuan beradaptasi terhadap kultur, 8) rasa kewarganegaraan yang profesional, dan 9) kemampuan merasakan kebahagiaan atas sebuah pekerjaan (Brown: 2011) menyatakan karakteristik seorang tenaga pengjar yang baik, seha-rusnya memenuhi karakter: 1) technical knowledge, pedagogial skills, interpersonal skills, dan personal qualiites. Brown (2001: 64) menyatakan 'beginning students are highly dependent on the teacher for models of language, and so a teacher-centered or teacher-fronted classroom is appropiate for some of your classroom time.' Selain tenaga pengajar, faktor karakteristik siswa yang berbeda dengan orang dewasa merupakan dasar bagi tenaga pengajar untuk menentukan metode yang akan digunakan dalam proses pembelajaran. Materi pembelajaran mencakup input yang akan diberikan kepada siswa berdasarkan silabus dan disesuaikan berdasarkan kebutuhan siswa dalam proses pembelajaran, sedangkan proses evaluasi di akhir pembelajaran diperlukan untuk mengetahui dan mengukur seberapa besar keberhasilan dari sebuah proses pembelajaran.

Metode survey yang dilakukan dengan menggunakan lembar observasi terhadap sistem pembelajaran di kelas. Parameter yang diamati untuk penelitian ini lebih menitik beratkan pada metode pengajaran Bahasa Inggris yang digunakan oleh guru, yaitu metode TPR (Total Physical Response).

\section{PEMBAHASAN}

Peneliti kemudian mencoba mengamati suatu kelas bahasa yang menggunakan metode TPR dalam pengajarannya. Peneliti dalam hal ini tidak akan melihat baik buruk maupun bagaimana proses pengajaran tersebut berlangsung, namun lebih kepada melihat kepada pemerolehan bahasa kedua yang mereka (anak-anak) dapatkan dengan menggunakan metode TPR ini. Kelas merupakan kelas privat bahasa Inggris, dengan jumlah siswa sebanyak 5 
orang yaitu (N, S, I, A, IR, F). Kelimanya duduk di bangkuTK. Guru adalah seorang pengajar bahasa Inggris yang mempunyai latar belakang bahasa Inggris dan pengalaman mengajar anak-anak cukup lama. Data diambil pada hari Senin, 11 Januari 2016 (16.00-17.00) di salah satu tempat kursus bahasa di Yogyakarta.

Pada sesi pertama, guru memberikan input kepada siswa berupa kata, frase, dan kemudian baru kalimat dalam bahasa Inggris. Guru memberi contoh terlebih dahulu, selanjutnya siswa mempraktekkan dengan teman/ partnernya. Misalnya ketika guru mengucapkan kata 'Stand up' (siswa mendegarkan, kemudian berdiri), 'Sit down' (siswa mendengarkan, kemudian duduk), dsb sampai dengan bentuk sintaksis kalimat yang lebih rumit dan kompleks. Pada saat mendengarkan guru mengucapkan kalimat dalam bentuk perintah tersebut, siswa kemudian meresponnya dengan melakukan tindakan yang sesuai dengan apa yang dikatakan oleh guru. Ini berarti bahwa meskipun anak tersebut belum bisa bicara dalam bahasa kedua, dalam hal ini bahasa Inggris, dia mencetak suatu peta linguistik bagaimana bahasa itu bekerja. Secara diam-diam, anak-anak tersebut menghayati pola dan suara dari bahasa target. Ketika anak tersebut telah cukup dalam membaca bahasa isyarat pada bahasa target, proses bicara muncul secara spontan pada anak tersebut. Cara bicara sang anak tidak akan sempurna, tetapi secara bertahap ungkapan-ungkapan anakanak tersebut akan semakin mendekati bahasa target.

Pada sesi kedua, guru memainkan beberapa permainan sebagai bentuk aplikasi dari metode TPR. Guru menggunakan permainan 'simon says'. Guru memberikan instruksi kepada siswa untuk melakukan permainan simon says, dengan tahap: 1) semua siswa berdiri dan mengikuti perintah dari guru, 2) apabila guru meminta siswa untuk melakukan suatu tindakan maka guru mengucapkan 'simon says' sebelum kalimat perintah yang diucapkan. Misalnya:'Simon says, close the door, please!'. Namun apabila instruksi yang diperintahkan oleh guru tidak didahului dengan 'simon says', maka siswa tidak diperbolehkan melakukan aksi tersebut. Misalnya: 'Touch your friend's bag!' (karena tidak didahului dengan 'simon says', maka siswa tidak boleh melakukan perintah tersebut). Permainan kemudian dilanjutkan dengan guru sebagai fasilitator dan siswa bermain dengan teman sekelasnya bergantian, sebagai inividu pemberi instruksi dan individu yang melaksanakan intruksi yang diberikan oleh temannya secara in-pair maupun group work.

Pada sesi kedua ini siswa kemudian dibekali pula ekspresi merespon terhadap perintah maupun larangan yang diberikan oleh lawan mainnya dalam permainan. Contoh ekpresi dan response yang digunakan sebagai berikut:

Tabel 3. Contoh ekspresi dan cara merespon

\begin{tabular}{ll}
\hline \multicolumn{1}{c}{ Ekspresi } & \multicolumn{1}{c}{ Respon } \\
\hline $\begin{array}{l}\text { Open your dictionary, } \\
\text { please }\end{array}$ & Okay!/Sure!/I will \\
Clean the board, please. & Alright/Yes, Mom \\
Throw the rubbish, & With a pleasure \\
please & \\
Get the magazie, & Sorry, not now, \\
please & please \\
Hold the books for me, & I'm sorry, I can't \\
please & do it \\
Move the teable, & I'm afraid, I can't \\
please & do it \\
\hline
\end{tabular}

\section{PENUTUP}

Sebagai suatu alternatif dalam pendekatan pembelajaran, akhirnya peneliti menyimpulkan metode TPR sebagai berikut: (1) metode ini menyenangkan, siswa menikmatinya dan ini bisa menjadi penggerak suasana kelas, (2) mudah diingat dan dapat menolong siswa mengingat frase dan kata, (3) memungkinkan perkembang- 
an belajar maksimal untuk siswa tipe kinestetik yang perlu aktif dalam kelas, (4) dapat digunakan dalam kelas kecil maupun besar, tidak menjadi masalah seberapa banyak siswa yang dimiliki sepanjang guru memiliki persiapan matang, siswa akan mengikuti, (5) metode ini berjalan baik dalam kelas dengan kemampuan siswa yang heterogen, gerakan-gerakan fisik bertemu dan secara lisan sehingga seluruh siswa mampu memahami dan menggunakan bahasa target, (6) tidak menuntut banyak persiapan materi, selama guru jelas dengan apa yang ingin dipraktekkan dan tidak akan memakan waktu lama untuk siap, (7) TPR sangat efektif digunakan untuk siswa di kelas-kelas pemula, (8) metode ini melibatkan otak kanan dan kiri secara berkesinambungan, dan (9) aktivitas TPR dapat menghadirkan masukan auditoris maupun aktivitas fisik, yang sesungguhnya sejalan dengan karakteristik anak pada usia tersebut dalam mempelajari bahasa kedua mereka.

Namun demikian, peneliti juga menemukan bahwa TPR sebagai sebuah metode ternyata juga memiliki keterbatasan. Ia sangat efektif pada tingkat awal kecakapan bahasa, tetapi menjadi kehilangan sifat pembedanya begitu pembelajar meningkat kompetensinya. Singkatnya, bahwa TPR memang dapatmeningkatkan tahap awal kemampuan berbahasa Inggris pada anak-anak, khususnya ketika mereka berada pada fase-fase awal di masa perkembangan intelektual dan perkembangan bahasa mereka. Namun menjadi kurang efektif ketika pembelajar beranjak menjadi pembelajar dewasa dan meningkat kompetensinya.

\section{DAFTAR PUSTAKA}

Asher, J (1977). Learning another language through actions: The complete teacher's guidebook. Los Gatos, CA: Sky Oaks Productions.

Brown, H Douglas. (2007). Prinsip Pembelajaran dan Pengajaran Bahasa. Edisi Kelima. Jakarta: The Public Affairs Section U.S Embassy

Brown, H Douglas. (2001). Teaching by Principles. An Interactive Approach to Language Pedagogy. Second Edition. San Fransisco University: Longman.

Cakrawala Pendidikan. Jurnal Ilmiah Pendidikan. (2005). Universitas Negeri Yogyakarta: Lembaga Pengabdian Kepada Masyarakat.

Harmer, Jeremy. (2001). The Practice Of English Language Teaching. England: Longman.

Syarkawi. (2008). Pembentukan Kepribadian Anak.Peran Moral, Intellektual, Emosional, dan Sosial sebagai Wujud integritas Membangun Jati Diri. Jakarta: Bumi Aksara.

Steinberg. (2000). Psycholinguistics: Language, Mind, and World. Second Edition. Longman: Pearson Education

Smith, Ronald E. Dan Passer, Michael W. (tt). Psychology. The Science of Mindand Behavior. Fourth Edition. Mc Graw Hill International: US

Woolfolk, Anita E. (1995). Educational Psychology. Sixth Edition. United States of America: A Simon and Shuster Company 